\title{
Anesthesia-Induced Hyperphosphorylation Detaches 3- Repeat Tau from Microtubules without Affecting Their Stability In Vivo
}

\author{
Emmanuel Planel, ${ }^{1}$ Pavan Krishnamurthy, ${ }^{1}$ Tomohiro Miyasaka, ${ }^{2}$ Li Liu, ${ }^{1}$ Mathieu Herman, ${ }^{1}$ Asok Kumar, ${ }^{3}$ \\ Alexis Bretteville, ${ }^{1}$ Helen Y. Figueroa, ${ }^{1}$ Wai Haung Yu, ${ }^{1}$ Robert A. Whittington, ${ }^{4}$ Peter Davies, ${ }^{5}$ Akihiko Takashima, ${ }^{6}$ \\ Ralph A. Nixon, ${ }^{3}$ and Karen E. Duff ${ }^{1}$ \\ ${ }^{1}$ Taub Institute for Alzheimer's Disease Research, Department of Pathology, Columbia University Medical Center, New York, New York $10032,{ }^{2}$ Faculty of \\ Life and Medical Sciences, Department of Medical Life Systems, Doshisha University, Kyoto 610-0394, Japan, ${ }^{3}$ Center for Dementia Research, Nathan S. \\ Kline Institute for Psychiatric Research, Orangeburg, New York 10962, ${ }^{4}$ Department of Anesthesiology, Columbia University, New York, New York 10027 , \\ ${ }^{5}$ Department of Pathology, Albert Einstein College of Medicine, Bronx, New York 10461, and ${ }^{6}$ The Institute of Physical and Chemical Research (RIKEN), \\ Brain Science Institute, Laboratory for Alzheimer's Disease, Wako-shi, Saitama, 351-0198, Japan
}

In Alzheimer's disease, tau is hyperphosphorylated, which is thought to detach it from microtubules (MTs), induce MT destabilization, and promote aggregation. Using a previously described in vivo model, we investigated whether hyperphosphorylation impacts tau function in wild-type and transgenic mice. We found that after anesthesia-induced hypothermia, MT-free tau was hyperphosphorylated, which impaired its ability to bind MTs and promote MT assembly. MT-bound tau was more resistant to hyperphosphorylation compared with free tau and tau did not dissociate from MTs in wild-type mice. However, 3-repeat tau detached from MT in the transgenic mice. Surprisingly, dissociation of tau from MTs did not lead to overt depolymerization of tubulin, and there was no collapse, or disturbance of axonal MT networks. These results indicate that, in vivo, a subpopulation of tau bound to MTs does not easily dissociate under conditions that extensively phosphorylate tau. Tau remaining on the MTs under these conditions is sufficient to maintain MT network integrity.

Key words: tau phosphorylation; microtubules; Alzheimer's disease; anesthesia; hypothermia; tubulin

\section{Introduction}

Tau is a microtubule-associated protein that is abundant in the CNS and expressed mainly in axons. In the human brain, tau is encoded by a single gene of 16 exons, generating 6 isoforms of 352-441 aa. Exons 9-12 encode the microtubule (MT) binding repeats, and alternate splicing of exon 10 generates tau with either three $(3 \mathrm{R})$ or four $(4 \mathrm{R})$ repeats. These repeat regions bind to MTs, and promote MT stabilization and polymerization. These functions are negatively regulated by phosphorylation at multiple sites in, and around, the MT binding domain (Buée et al., 2000; Avila et al., 2004).

In Alzheimer's disease (AD) and other tauopathies, hyperphosphorylated tau protein aggregates and forms paired helical filaments (PHF) that are the main component of intraneuronal

\footnotetext{
Received Aug. 27, 2008; accepted 0ct. 15, 2008.

This work was supported by National Institute of Neurological Disorders and Stroke Grant NS048447 and National Institute of Aging Grant AG017216 (to K.E.D.). We thank Dr. Aidong Yuan and Corrine M. Peterhoff (Nathan S. Kline Institute for Psychiatric Research, Center for Dementia Research, Orangeburg, NY) for technical assistance. We are grateful to Drs. Rohan de Silva (University College, London, UK), and Peter A. Seubert (Athena Neuroscience Inc., San Francisco, CA), for the generous gift of antibodies. Our gratitude also goes to Prof. Alejandra del C. Alonso (City University of New York, College of Staten Island, Staten Island, NY) for help with the assembly assay.

Correspondence should be addressed to Dr. Karen E. Duff, Columbia University Medical Center, Taub Institute for Alzheimer's Disease Research, Department of Pathology, P\&S\#12-440, 630 West 168th Street, New York, NY 10032. E-mail:ked2115@columbia.edu.

DOI:10.1523/JNEUROSCI.4101-08.2008

Copyright $\odot 2008$ Society for Neuroscience $\quad 0270-6474 / 08 / 2812798-10 \$ 15.00 / 0$
}

neurofibrillary tangles (NFT) primarily found in the somatodendritic compartment of affected neurons. The appearance of aggregated tau correlates with a loss of MTs and a breakdown of axonal flow (Terry, 1996; Pollak et al., 2003). Thus, the hyperphosphorylation of tau by the deregulation of kinases and/or phosphatases has been proposed to dissociate tau from MTs, thereby destabilizing the MTs and disrupting MT-dependent axonal transport (Trojanowski and Lee, 1994; Mandelkow et al., 2003; Feinstein and Wilson, 2005; Mi and Johnson, 2006). In vitro studies have demonstrated that hyperphosphorylation of tau can indeed induce MT disruption (Ebneth et al., 1999), as well as tau aggregation (Alonso et al., 2001; Sato et al., 2002). However, there is a lack of evidence from in vivo studies to support the assumption that tau hyperphosphorylation detaches tau from microtubules and results in MT breakdown.

To examine MT and tau dynamics in response to phosphorylation, we induced tau hyperphosphorylation in mice by exposing the animals to anesthesia. We have shown previously that anesthesia-induced hypothermia promotes extensive tau hyperphosphorylation at multiple epitopes by directly inhibiting ser/ thr protein phosphatase 2A (Planel et al., 2007b). This model system replicates what is seen in the AD brain as decreased PP2A expression (Vogelsberg-Ragaglia et al., 2001; Sontag et al., 2004), and upregulation of its inhibitors (Tanimukai et al., 2005), result in overall inhibition of its activity (Gong et al., 1993; Gong et al., 
1995). PP2A inhibition has been proposed to be an important factor in the evolution of the pathology of AD (Tian and Wang, 2002).

Our results show that hyperphosphorylation impaired tau's ability to bind and polymerize MTs, but did not detach it from MTs in normal mice. Hyperphosphorylation of tau in transgenic mice expressing all six isoforms of human tau (hTau mice) led to specific dissociation of $3 \mathrm{R}$ from the MTs in old mice. Neither normal nor hTau mice however, displayed a breakdown of MTs. These results demonstrate that $4 \mathrm{R}$ tau is tightly bound to MTs and does not readily dissociate, whereas $3 \mathrm{R}$ is more sensitive to the effects of phosphorylation, thus resulting in dissociation from the MTs. However, this dissociation does not lead to catastrophic collapse of the MT network.

\section{Materials and Methods \\ Animals}

Adult C57BL/6J (Jackson Laboratory) or hTau mice (Andorfer et al., 2003) of either sex were used at 3-4 month-old (young mice) or 18-20 month-old (old mice). Animals were used according to National Institute of Health/Institutional Animal Care and Use Committee Guidelines.

\section{Anesthesia}

Anesthesia was induced by intraperitoneal injections of pentobarbital (Nembutal, $100 \mathrm{mg} / \mathrm{kg}$; Abbot Laboratories), and the animals were kept at room temperature for 1 or $4 \mathrm{~h}$ before killing. Mice were killed by cervical dislocation, brains were removed and the tissue was dissected quickly. The whole process took $<1 \mathrm{~min}$. The control injections were performed with vehicle (50\% water, $40 \%$ propylene glycol, $10 \%$ ethanol). Mouse body temperature was monitored with a rectal probe (Thermalert TH-5, Physitemp).

\section{Microtubule assays}

We performed 3 microtubule assays. The first preserves the association of tau and MTs found in the brain, and is thus called here Endogenous Microtubule Binding Assay because it examines the association of endogenous tau to endogenous MTs. The second assay dissociates endogenous tau from endogenous microtubules and examine the association of tau with preformed bovine microtubules; it is called here Exogenous Microtubule Binding Assay. The third one is a MT Assembly Assay performed with bovine tubulin and endogenous tau.

Endogenous microtubule binding assays. To determine whether tau hyperphosphorylation could detach tau from microtubules, a MT binding assay was performed using a modification of previously reported procedures (Bramblett et al., 1993; Merrick et al., 1996; Vogelsberg-Ragaglia et al., 2000). After dissection, fresh cortices were immediately homogenized in $5 \times$ weight/volume of prewarmed $\left(37^{\circ} \mathrm{C}\right)$ modified reassembly $(\mathrm{RA})$ buffer (0.1 MES, pH 6.5; 0.5 mm $\mathrm{MgSO}_{4} ; 2$ mм GTP; 1 mм EGTA; 2 mM DTT; $20 \mu \mathrm{M}$ taxol; 0.1\% Triton X-100; $1 \mathrm{~mm}$ PMSF; 1 mM Na $\mathrm{VO}_{4} ; 1 \mathrm{~mm}$ $\mathrm{NaF} ; 10 \mu \mathrm{l} / \mathrm{ml}$ Sigma Protease Inhibitor Cocktail P8340), in a warm $\left(37^{\circ} \mathrm{C}\right)$ glass-Teflon homogenizer (Weisenberg, 1972; Bramblett et al., 1993). The lysate was then immediately centrifuged at $3,000 \times g$ for $2 \mathrm{~min}$ at $25^{\circ} \mathrm{C}$ to remove the debris. An aliquot $(100 \mu \mathrm{l})$ of the supernatant was sampled, dissolved in $400 \mu \mathrm{l}$ of $\mathrm{O}+$ buffer (62.5 mm Tris-HCl, $\mathrm{pH} 6.8$; 10\% glycerol; 5\% 2-mercaptoethanol; 2.3\% SDS; 1 mM EGTA; $1 \mathrm{~mm}$ EDTA; 1 mM PMSF; 1 mM Na $V_{3} \mathrm{VO}_{4} ; 1$ mM NaF; $10 \mu \mathrm{l} / \mathrm{ml}$ Protease Inhibitor Cocktail P8340, Sigma-Aldrich), a modified O buffer (O'Farrell, 1975), and boiled for $5 \mathrm{~min}$. This is the total fraction, which includes both MT-free and bound fractions. Another aliquot $(100 \mu \mathrm{l})$ of the supernatant was pelleted at $100,000 \times g$ for $20 \mathrm{~min}$ at $25^{\circ} \mathrm{C}$. The detergent-soluble supernatant was removed, and $80 \mu \mathrm{l}$ were diluted in $320 \mu \mathrm{l}$ of $\mathrm{O}+$ buffer and boiled for $5 \mathrm{~min}$. This was referred to as the MT-free fraction. The remaining pellet was resuspended in $100 \mu \mathrm{l}$ of RA buffer, and diluted in $400 \mu \mathrm{l}$ of $\mathrm{O}+$ buffer and boiled for $5 \mathrm{~min}$. This was referred to as the MT-bound fraction. Protein levels were quantified in all fractions.

We performed a similar assay with a buffer containing 30\% glycerol as a MT stabilizer instead of taxol and GTP (Shelanski et al., 1973). This is an alternate technique also well documented (Esmaeli-Azad et al., 1994;
Xie et al., 1998). Briefly, after dissection, fresh cortices were immediately homogenized in $5 \times$ weight/volume of prewarmed $\left(37^{\circ} \mathrm{C}\right)$ extraction buffer (80 mM MES, pH 6.8; 1 mM $\mathrm{MgCl}_{2} ; 2$ m EGTA; 30\% glycerol; $0.1 \%$ Triton X-100; $1 \mathrm{~mm}$ PMSF; $1 \mathrm{~mm} \mathrm{Na}_{3} \mathrm{VO}_{4} ; 1 \mathrm{~mm} \mathrm{NaF} ; 10 \mu \mathrm{l} / \mathrm{ml}$ Sigma Protease Inhibitor Cocktail P8340), in a warm $\left(37^{\circ} \mathrm{C}\right)$ glass-Teflon homogenizer. The lysate was then immediately centrifuged at 3,000 $\times g$ for $2 \mathrm{~min}$ at $25^{\circ} \mathrm{C}$ to remove the debris. An aliquot $(100 \mu \mathrm{l})$ of the supernatant was sampled, dissolved in $400 \mu \mathrm{l}$ of $\mathrm{O}+$ buffer and boiled for $5 \mathrm{~min}$. This is the total fraction, which includes both MT-free and bound fractions. Another aliquot $(100 \mu \mathrm{l})$ of the supernatant was pelleted at $100,000 \times g$ for $20 \mathrm{~min}$ at $25^{\circ} \mathrm{C}$. The detergent-soluble supernatant was removed, and $80 \mu \mathrm{l}$ were diluted in $320 \mu \mathrm{l}$ of $\mathrm{O}+$ buffer and boiled for 5 min. This was referred to as the MT free fraction. The remaining pellet was solubilized in $100 \mu$ l of RA buffer, and diluted in $400 \mu$ lof O+ buffer and boiled for $5 \mathrm{~min}$. This was referred to as the MT-bound fraction.

Exogenous microtubule binding assay. The microtubule-binding assay was performed as described previously (Maas et al., 2000), with a few modifications. Hemispheres were homogenized in $5 \times$ weight/volume of BRB80 (Brinkley Reassembly Buffer; 80 mM PIPES/KOH pH 6.8, 1 mM EGTA, $1 \mathrm{~mm} \mathrm{MgCl}_{2}$ ) with protease and phosphatase inhibitors. Homogenates were incubated on ice for $15 \mathrm{~min}$ and centrifuged at $20,000 \times \mathrm{g}$ for $20 \mathrm{~min}$ at $4^{\circ} \mathrm{C}$. Supernatants were re-spun at $100,000 \times g$ for $1 \mathrm{~h}$ at $4^{\circ} \mathrm{C}$. Equal amounts of protein lysate were used in each binding assay. Highspeed supernatant fractions were adjusted to $1 \mathrm{~mm}$ GTP and $10 \mu \mathrm{M}$ taxol and incubated with taxol-stabilized microtubules ( $30 \mu \mathrm{M}$, Cytoskeleton, Denver, CO) in a final volume of $50 \mu \mathrm{l}$ for $10 \mathrm{~min}$ at $37^{\circ} \mathrm{C}$. The mixtures were centrifuged through $100 \mu \mathrm{l}$ of $30 \%(\mathrm{w} / \mathrm{v})$ sucrose cushions in BRB80 containing $1 \mathrm{~mm} \mathrm{GTP}$ and $10 \mu \mathrm{M}$ taxol, at $100,000 \times g$ for $30 \mathrm{~min}$ at room temperature. The supernatant (MT free fraction) was collected and diluted with $\mathrm{O}+$ buffer, and the pellet (MT bound fraction) was resuspended in $\mathrm{O}+$ buffer.

Assembly assay. After dissection, cortices were homogenized in $5 \times$ weight/volume of modified RA buffer. Homogenates were centrifuged for $5 \mathrm{~min}$ at $3000 \times g$ at $4^{\circ} \mathrm{C}$. Supernatants were boiled for $5 \mathrm{~min}$ and respun at $100,000 \times g$ for $30 \mathrm{~min}$ at $4^{\circ} \mathrm{C}$. Supernatants were used to check total tau expression levels by Western blot using total tau antibody. The microtubule assembly assay was essentially performed as described previously with a few modifications (Alonso et al., 2006). Heat stable lysates containing $300 \mathrm{ng}$ of tau were mixed at $4^{\circ} \mathrm{C}$ with purified bovine brain MAP-free tubulin ( $5 \mathrm{mg} / \mathrm{ml}$, Cytoskeleton, Denver, CO) and $1 \mathrm{~mm}$ GTP, all in polymerization buffer (100 mM MES, pH 6.7, 1 mM EGTA, 1 mM $\mathrm{MgCl}_{2}$ ) in a final volume of $80 \mu \mathrm{l}$. After rapid mixing, the samples were pipetted into quartz microcuvettes in a thermostatically controlled Hewlett Packard 8453 UV-Visible spectrophotometer. After 30 s of equilibration at $37^{\circ} \mathrm{C}$, the turbidity of the reaction mixture was continuously monitored at $350 \mathrm{~nm}$ for $10 \mathrm{~min}$.

\section{Antibodies}

The following anti-tau monoclonal antibodies (specificity given in parentheses) were used: CP13, phospho-Ser ${ }^{202}$ (Weaver et al., 2000); TG-3, phospho-Ser ${ }^{231}$ and conformation specific; MC-6, phospho-Ser ${ }^{235}$ (Jicha et al., 1997); and PHF-1, phospho-Ser ${ }^{396} /$ Ser $^{404}$ (Otvos et al., 1994). Total tau was detected with either Tau T57120 (monoclonal, BD Transduction Laboratories), or Tau A0024 (polyclonal, Dako). AT8 (Pierce Biotechnology) reacts with tau phosphorylated at $\mathrm{Ser}^{202} / \mathrm{Thr}^{205}$ (Goedert et al., 1995), and Tau-1 (Millipore Bioscience Research Reagents) recognizes tau dephosphorylated at $\mathrm{Ser}^{195} / \mathrm{Ser}^{198} / \mathrm{Ser}^{199} / \mathrm{Ser}^{202}$ (Szendrei et al., 1993). Purified rabbit polyclonal anti-tau antibodies anti-tau phospho-Ser ${ }^{199}$, phospho-Ser ${ }^{262}$, and phospho-Ser ${ }^{422}$ were purchased from Biosource International. Antibody 12E8, which recognizes phospho-Ser ${ }^{262} /$ Ser $^{356}$ (Seubert et al., 1995), was provided by Dr. Peter A. Seubert (Athena Neuroscience). RD3 and RD4, specific for 3-repeat (3RT) and 4-repeat (4RT) tau, were a gift from Dr. Rohan de Silva (University College, London, UK). Monoclonal antibodies Anti- $\alpha$-Tubulin (B-5-1-2), Anti- $\beta$-Tubulin (TUB 2.1), Anti-Acetylated Tubulin (6-11B1), and Anti-Tyrosine Tubulin (TUB-1A2) were purchased from SigmaAldrich. Polyclonal anti-Detyrosinated Tubulin (Glu-Tubulin, AB3201), was bought from Millipore Bioscience Research Reagents. 


\section{Immunoblot analysis}

Membrane blocking and antibody incubations were performed as described (Planel et al., 2001), with appropriate primary and secondary antibody dilutions. Anti-mouse and anti-rabbit HRP-conjugated secondary antibodies were purchased from Jackson ImmunoResearch Laboratories. Immunoreactive bands were visualized and analyzed by enhanced chemiluminescence reagent (SuperSignal West Pico or Femto, Pierce Biotechnology) using a Fujifilm LAS3000 imaging system and the Image Gauge Mac OS X software. Serial dilutions of brain extract were assessed to obtain calibration curves for reliable quantification.

\section{Immunohistochemistry}

The brains of hTau mice, and tau knock-out mice were fixed by immersion in freshly prepared $4 \%$ paraformaldehyde (in PBS pH 7.4) overnight and cryoprotected in $30 \%$ sucrose solutions. Sagittal sections $(40 \mu \mathrm{m})$ were cut through the brain using a cryostat (model HM 505 E; Microm International Gmbh, Walldorf, Germany). Immunohistochemistry was performed on free-floating brain sections using SuperPicTure polymer detection kit (Zymed). Sections were washed with PBS for $10 \mathrm{~min}$, and some were treated with $3 \% \mathrm{H}_{2} \mathrm{O}_{2}$ in PBS with $0.25 \%$ Triton X-100 for 30 $\mathrm{min}$ at room temperature. For certain antibodies, epitope retrieval was also performed using sodium citrate buffer ( $10 \mathrm{~mm}$ sodium citrate, $0.05 \%$ Tween 20, pH 6.0) according to a standard protocol (Shi et al., 1993). The sections were then blocked with 5\% milk in PBS for $1 \mathrm{~h}$ at room temperature on a rotator, transferred to a Microfuge tube containing $1 \mathrm{ml}$ of primary antibody diluted in $5 \%$ milk in PBS and incubated at $4^{\circ} \mathrm{C}$ overnight. After three washes of 5 min in PBS with $0.05 \%$ Triton X-100, the sections were incubated for $2 \mathrm{~h}$ with biotin-labeled secondary antibody in $20 \%$ Superblock (Pierce, \#37535) in PBS with $0.05 \%$ Triton X-100. After washing, the sections were incubated $1 \mathrm{~h}$ with HRP polymer conjugate in $20 \%$ Superblock in PBS with $0.05 \%$ Triton X-100. After three washes, the staining was visualized using DAB chromogen. The stained sections were mounted on slides and coverslipped, and were examined using a Leica microscope.

\section{Electron microscopy}

Animals anesthetized briefly with isoflurane gas were perfused transcardially with $4 \%$ paraformaldehyde and $2.5 \%$ glutaraldehyde in $0.1 \mathrm{M}$ sodium cacodylate buffer, $\mathrm{pH} 7.2$, and optic nerve tract removed, postfixed overnight in the same fixative. Samples were postfixed with $1 \%$ osmium tetroxide, washed, dehydrated, and embedded in Epon-Araldite resin. The optic nerve was dissected and processed as described (Nixon et al., 1994). Thin sections of $1 \mu \mathrm{m}$ thick for light microscopy were stained with toluidine blue to identify the area of the optic nerve, and $70 \mathrm{~nm}$-thin sections for electron microscopy were stained with uranyl acetate and lead acetate before being examined with a transmission electron microscope (model CM 10; Philips). Images were captured on a CCD camera (model C4742-95; Hamamatsu Photonics, Hamamatsu) and on Advantage CCD Camera System software (Advanced Microscopy Techniques Corporation). Ultrastructural analyses of optic nerve were performed at a level $2 \mathrm{~mm}$ from the retinal excavation.

\section{Statistical analysis}

Statistical analysis was performed with a two-tailed $t$ test, except were indicated. Data are means $\pm \mathrm{SD}$ or SEM, as indicated in the figures; ${ }^{*},{ }^{* *}$, and ${ }^{* *}$ symbols indicate significant differences with $p<0.05, p<0.01$, and $p<0.001$, respectively.

\section{Results}

\section{In vivo tau hyperphosphorylation does not detach tau from microtubules in normal mice}

We first performed the endogenous MT binding assay on young nontransgenic mice exposed to pentobarbital anesthesia for $1 \mathrm{~h}$. After anesthesia, the body temperature rapidly dropped from $38.3 \pm 0.3^{\circ} \mathrm{C}$ to $29.2 \pm 0.2^{\circ} \mathrm{C}$. Although tau was significantly hyperphosphorylated, there was no change in the amount of tau bound to MTs compared with the tau in the MT-free fraction (data not shown). Thus hyperphosphorylation of tau for $1 \mathrm{~h} \mathrm{did}$ not lead to its detachment from MTs in nontransgenic mice. We next examined whether longer exposure to hyperphosphorylation might be required to detach tau from MTs by analyzing the mice $4 \mathrm{~h}$ after the induction of anesthesia. After $4 \mathrm{~h}$, the rectal temperature of the mice was $27.2 \pm 0.1^{\circ} \mathrm{C}$. Tau was highly phosphorylated at all epitopes analyzed, in both the total and free fractions (Fig. 1A, B, $\mathrm{S}^{202} / \mathrm{T}^{205}$ (AT8) and $\mathrm{S}^{396} / \mathrm{S}^{404}$ (PHF-1) epitopes displayed). As a result of hyperphosphorylation, tau underwent a mobility shift in the total and free fractions which was observed as a primary single band at $56 \mathrm{kDa}$ and a minor band at $50 \mathrm{kDa}$ in the control mice, compared with a primary doublet band at $60 \mathrm{kDa}$, and 3 minor bands at 56, 64 and $70 \mathrm{kDa}$ after anesthesia (Fig. 1C). The phosphorylation pattern of tau bound to MTs was also different, with no significant phosphorylation of $\mathrm{S}^{202} / \mathrm{T}^{205}$ (AT8), $\mathrm{T}^{231}, \mathrm{~S}^{235}, \mathrm{~S}^{262} / \mathrm{S}^{356}(12 \mathrm{E} 8)$, and $\mathrm{S}^{422}$ epitopes (Fig. $1 A, \mathrm{~S}^{202} / \mathrm{T}^{205}$ epitope displayed), and significant hyperphosphorylation at $S^{396} / S^{404}, S^{199}$, and $S^{202}$ being observed in the anesthetized animals (Fig. 1 B, PHF-1 epitope displayed). The mobility shift of tau in the bound fraction was less pronounced than in the other fractions, with a primary band at $56 \mathrm{kDa}$ being observed in both control and anesthetized mice, and no clear bands at 64 and $70 \mathrm{kDa}$. There was no significant change in either $\alpha$-, $\beta$-, Tyr-, Glu- or Ac-tubulin in any of the fractions (Fig. $1 D$, $\alpha$-tubulin displayed). These results indicate that anesthesiainduced tau hyperphosphorylation for $4 \mathrm{~h}$ does not detach tau from MTs, and does not destabilize MTs in normal mice. Interestingly, hyperphosphorylated tau detected in the total fraction mostly reflected tau from the free fraction. Tau bound to the MTs in the pelleted fraction appeared to be more resistant to hyperphosphorylation at some of the epitopes examined $\left(S^{202} / \mathrm{T}^{205}\right.$, $\mathrm{T}^{231}, \mathrm{~S}^{235}, \mathrm{~S}^{262} / \mathrm{S}^{356}$, and $\mathrm{S}^{422}$ ). This assay was performed using taxol to protect the MTs during the extraction process. Although this technique is standard in the field and has been used by many (Bramblett et al., 1993; Merrick et al., 1996; Vogelsberg-Ragaglia et al., 2000), it should be noted that taxol is a powerful stabilizer of MT, and published data demonstrate that incubation at $37^{\circ} \mathrm{C}$ with taxol will displace all of the soluble tubulin in the bound fraction (Xie et al., 1998). In our protocol, our samples are not incubated with taxol: we spin the homogenate immediately after extraction, and taxol is included only to prevent breakdown of MTs during the extraction process. Nevertheless, to verify that our results are not attributable to an artifact stemming from the presence of taxol, we performed the assay with a buffer containing 30\% glycerol instead of taxol and GTP (Shelanski et al., 1973). This alternate technique is used by many groups (Esmaeli-Azad et al., 1994; Xie et al., 1998). The use of either taxol or glycerol demonstrated anesthesia-induced hyperphosphorylation of tau, with no detachment of tau from microtubules and no shift of tubulin in the free fraction (supplemental Fig. 1S, available at www.jneurosci.org as supplemental material). Finally, we performed the assay without taxol or glycerol and found similar results (data not shown).

\section{In vivo tau hyperphosphorylation prevents tau from binding and assembling microtubules}

Our above data suggest that hyperphosphorylation does not detach tau from MTs in normal mice. To examine whether hyperphosphorylation alters the ability of tau to bind and stabilize MTs we compared the binding of tau from anesthetized and control mouse brain to exogenous, preformed MT. There was less tau in the MT bound fraction and more in the free fraction in anesthetized mice compared with controls (Fig. $2 \mathrm{~A}$ ) for equivalent amounts of tubulin (Fig. 2B). These results indicate that in vivo, hyperphosphorylation impaired tau's capacity to bind preas- 

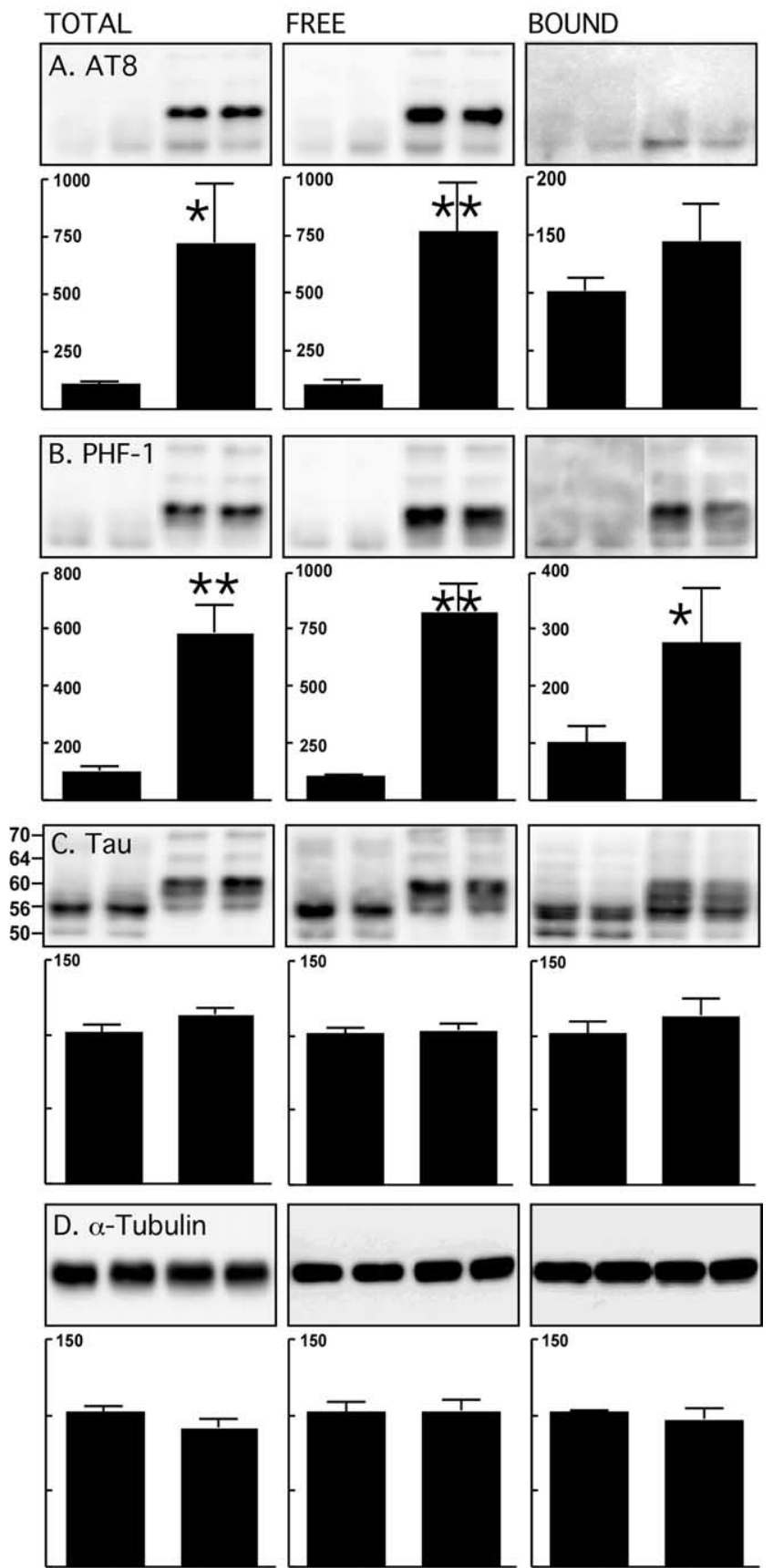

$\mathrm{Ctl}$

Anes
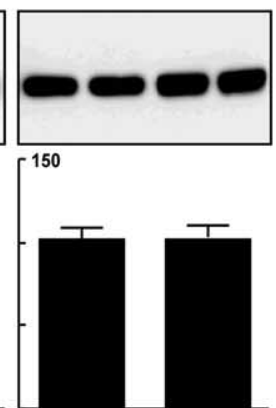

$\mathrm{Ctl}$

Anes

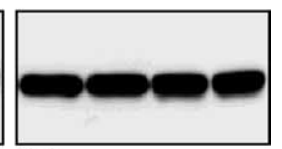

150

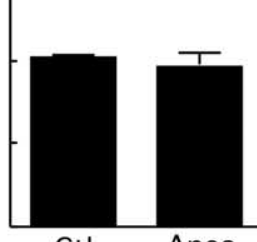

Ctl

Anes

Figure 1. Endogenous microtubule binding assay of tau after anesthesia in nontransgenic mice. Brain lysates (neocortex) from control mice and mice anesthetized for $4 \mathrm{~h}$ with pentobarbital were prepared. Tau and tubulin from total, free, and bound fractions were evaluated by immunoblot analysis with the following antibodies: $\boldsymbol{A}$, AT8 $\left(\mathrm{pS}^{202} / \mathrm{pT}^{205}\right) ; \boldsymbol{B}$, PHF-1 $\left(\mathrm{pS}^{396} /\right.$ $\mathrm{pS}^{404}$ ); $\boldsymbol{C}$, Tau (phospho-independent, molecular weights in $\mathrm{kDa}$ indicated on the left); $\boldsymbol{D}$, $\alpha$-tubulin. Bar graphs represent the quantification of the immunoblot bands displayed above them. Each graph displays the immunoreactivity expressed as a percentage of the control $(100 \%)$. Numbers in the graphs indicate the percentage of the tick line with which they are aligned. Data represented are means $\pm S D(n=4$ for each condition, 2 representative data displayed, each lane represents an individual mouse). Asterisks indicate significant differences from controls, with ${ }^{*} p<0.05$ and ${ }^{* *} p<0.01$.

sembled MT. We next performed a MT assembly assay using purified bovine tubulin, and tau from control, or anesthetized mouse brains. Hyperphosphorylated tau from anesthetized mice was less efficient at promoting MT assembly than tau from con-

FREE
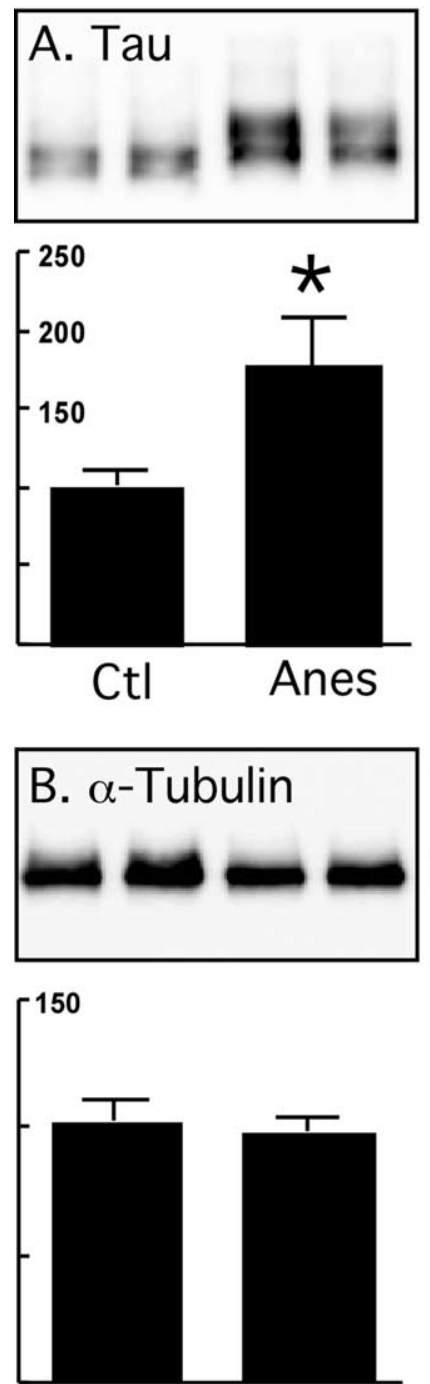

Ctl
BOUND
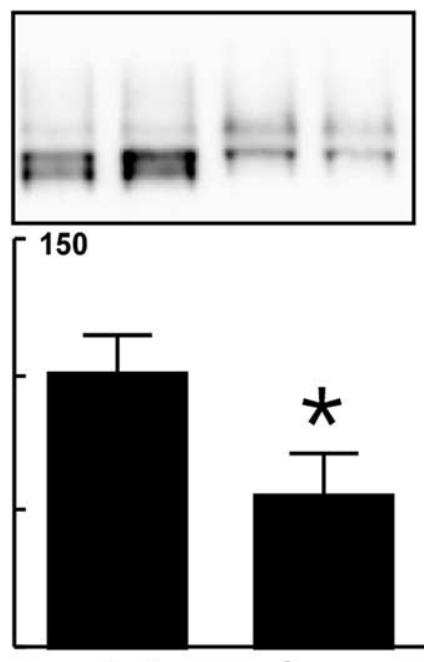

Ctl Anes
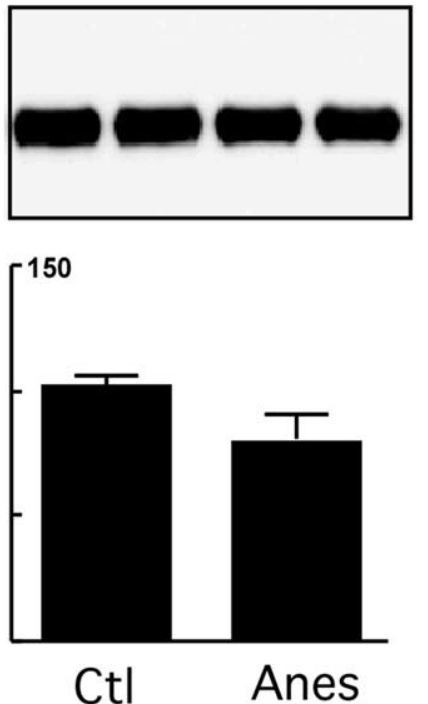

Figure 2. Exogenous microtubule binding assay of tau after anesthesia in nontransgenic mice. Brain proteins (neocortex) from control mice and mice anesthetized for $4 \mathrm{~h}$ with pentobarbital were extracted and incubated with taxol-stabilized microtubules. Tau and tubulin levels from MT free and bound fractions were evaluated by immunoblot analysis with the following antibodies: $\boldsymbol{A}$, Tau (phospho-independent); $\boldsymbol{B}, \alpha$-tubulin. Bar graphs represent the quantification of the immunoblot bands displayed above them. Each graph displays the immunoreactivity expressed as a percentage of the control (100\%). Numbers in the graphs indicate the percentage of the tick line with which they are aligned. Data represented are means $\pm S D(n=4$ for each condition, 2 representative data displayed, each lane represents an individual mouse). Asterisks indicate significant differences from controls, with ${ }^{*} p<0.05$.

trol brains (Fig. 3). To perform this assay, we used tau from the heat-stable fraction which, however enriched in tau, contains other microtubule associated proteins that could be responsible for the differences in MT assembly rates between control and anesthetized mice. To exclude this possibility, we next performed the same assay with mice lacking tau (tau KO). Heat-stable fractions showed no difference between control and anesthetized tau KO mice (supplemental Fig. $2 S$, available at www.jneurosci.org as supplemental material), demonstrating that the effect of anesthesia on MT assembly are mediated through tau phosphorylation. Overall these results demonstrate that hyperphosphorylation impairs tau's ability to bind, and promote MT assembly. 


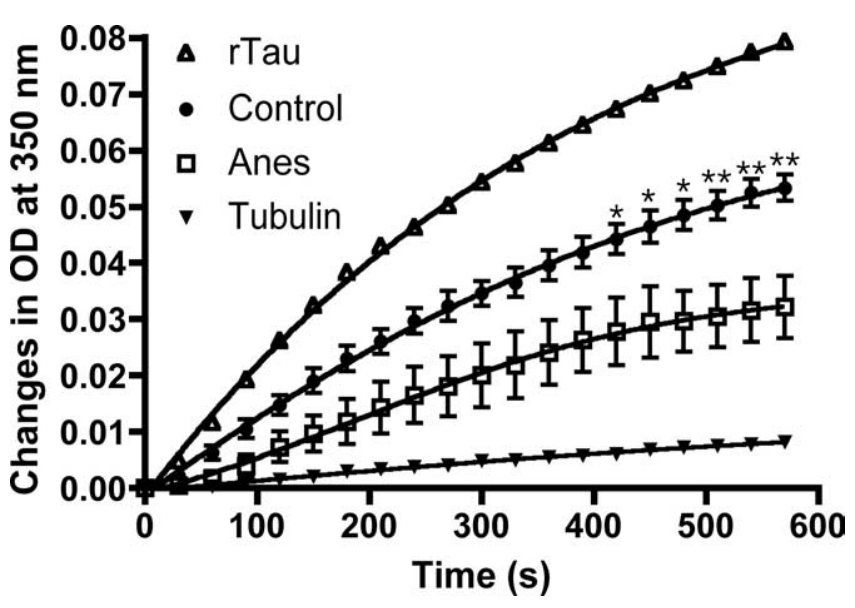

Figure 3. Microtubule assembly assay of tau after anesthesia in nontransgenic mice. Brain homogenates (neocortex) from control mice and mice anesthetized for $4 \mathrm{~h}$ with pentobarbital were prepared, and $300 \mathrm{ng}$ of tau from the heat stable fractions was used to assemble MAP-free tubulin for $10 \mathrm{~min}$ at $37^{\circ} \mathrm{C}$. Tubulin alone (solid triangles) and $300 \mathrm{ng}$ of recombinant tau (rTau, open triangles) were used as negative and positive assembly controls, respectively. Tau from anesthetized (Anes, open squares) mice assembled MT slower than tau from control (Control, solid circles) mice ( $n=3 ; p<0.0001$; two-way ANOVA followed by Bonferroni's posttest). For control and anesthetized mice, each point represents the mean \pm SEM of three separate experiments with three different mice. Asterisks indicate significant differences, with ${ }^{*} p<0.05$ and ${ }^{* *} p<0.01$.

\section{In vivo tau hyperphosphorylation in hTau mice detaches tau from MT}

In the $\mathrm{AD}$ brain, hyperphosphorylation has been proposed to lower the levels of MT bound tau below a critical threshold, thereby leading to destabilization of the MTs (Trojanowski and Lee, 1994). One possible reason why we did not observe this in our study is that mouse and human tau differ in the ratio of the isoforms, and mouse tau might be more difficult to detach from MT because of the fact that it is all 4R. To examine this possibility, we repeated our experiments in a line of mice that expresses all six isoforms of human tau in the absence of mouse tau (Duff et al., 2000; Andorfer et al., 2003).

We first performed the experiment in young hTau mice that do not yet have tau pathology. After $4 \mathrm{~h}$ of anesthesia, the average body temperature fell to $28.9 \pm 2.6^{\circ} \mathrm{C}$. As in non-TG mice, there was no detachment of tau from MTs or shift of tubulin to the unbound fraction (data not shown). One possible cause why hyperphosphorylation does not detach tau from the MT during anesthesia, whereas it would putatively detach in $\mathrm{AD}$, would be that anesthesia-induced tau hyperphosphorylation levels are much lower than in AD. To exclude this possibility, we compared tau phosphorylation between anesthetized non-TG and hTau mice, and AD brains at Braak stage VI. There was no significant difference in phospho-tau levels (adjusted by total tau) between the 3 groups, indicating that, in theory, hyperphosphorylation levels reached during anesthesia should be enough to detach tau from MTs (supplemental Fig. 3S, available at www.jneurosci.org as supplemental material).

Another possibility why there is no change, is that the duration of tau phosphorylation during anesthesia $(4 \mathrm{~h})$ is not long enough to bring about detachment of tau and collapse of MTs. To address this possibility, we performed the same assay in mice starved for $3 \mathrm{~d}$. Starvation induces hypothermia and extensive tau hyperphosphorylation (Planel et al., 2001; Planel et al., 2004). Interestingly, starvation led to greater phosphorylation of tau in the MT-bound fraction at certain epitopes such as AT8, but not at others such as $\mathrm{pS}^{262}$. However, there was still no detachment of tau from MTs or collapse of MTs (supplemental Fig. 4S, available at www.jneurosci.org as supplemental material).

To verify wether tau pathology influences the stability of the MT network, we then performed the same assay in old hTau mice that have mild pathology and somatodendritic relocalization of tau. In control mice, tau consisted of a doublet at 54 and $56 \mathrm{kDa}$, with another band at $60 \mathrm{kDa}$, and two minor bands at 51 and 67 $\mathrm{kDa}$ (Fig. 4C). After anesthesia, hyperphosphorylation was seen as a slight upward mobility shift of all of the bands between 54 and $67 \mathrm{kDa}$, with stronger bands at 56 and $60 \mathrm{kDa}$ in the total fraction. Tau was hyperphosphorylated at $\mathrm{S}^{202} / \mathrm{T}^{205}$ (AT8) and $\mathrm{S}^{396} / \mathrm{S}^{404}$ (PHF-1) sites in both total and free fractions, but was not significantly hyperphosphorylated in the bound fraction (Fig. $4 A, B$ ). Other phosphorylation sites followed the same trend (data not shown). In addition, there was more tau in the free fraction and less tau in the bound fraction (Fig. 4C). No change in $\alpha-, \beta$-, Tyr-, Glu- or Ac-tubulin was observed in any fraction (Fig. $4 D$, $\alpha$-tubulin shown). The same experiment performed in old non-TG mice did not lead to tau detachment from MTs (data not shown). Moreover, comparison of the levels of tau phosphorylation in control and anesthetized non-TG and hTau mice showed that, although tau phosphorylation is significantly higher in hTau control mice relative to total tau levels, the extent of hyperphosphorylation during anesthesia is similar in both mice (supplemental Fig. 5S, available at www.jneurosci.org as supplemental material). Together, these data suggest that detachment of tau from MTs during anesthesia in old hTau mice is not dependent on age or on the levels of tau phosphorylation, but on the extent of tau pathology. They also indicate that hyperphosphorylation can detach a fraction of human tau from MT without destabilizing them.

\section{Hyperphosphorylated 3R tau detaches from MTs in}

hTau mice

One of the main differences between mouse and humans with respect to tau is that adult humans continue to express $3 \mathrm{R}$ tau in addition to $4 \mathrm{R}$ tau, whereas adult mice only express $4 \mathrm{R}$ tau (Janke et al., 1999). To examine the isoform composition in the different fractions, immunoblots were prepared using antibodies specific to $3 \mathrm{R}$ or $4 \mathrm{R}$ tau (Andorfer et al., 2003; de Silva et al., 2003). There was more $3 \mathrm{R}$ tau in the free and less in the bound fraction after $4 \mathrm{~h}$ of anesthesia (Fig. 5A). 4R tau levels did not change in either fraction (Fig. 5B). This result was confirmed using ET1 (Andorfer et al., 2003), another $4 \mathrm{R}$ tau antibody (data not shown). Thus, in vivo, hyperphosphorylated $3 \mathrm{R}$ tau detaches from MTs more readily than $4 \mathrm{R}$ tau.

\section{Anesthesia leads to neuropil and somatic tau}

\section{hyperphosphorylation in hTau mice}

We previously reported the immunohistochemical analysis of anesthetized nontransgenic mice and demonstrated that hyperphosphorylated tau was localized in the neuropil and axonal tracks of anterior areas without somatodendritic relocalization (Planel et al., 2007b). Here, we examined the distribution of phospho-tau in control and anesthetized old hTau mice with antibodies recognizing tau phosphorylated at $\mathrm{S}^{202} / \mathrm{T}^{205}$ (AT8) and $S^{396} / S^{404}$ (PHF-1). AT8 showed weak staining in control mice (Fig. $6 \mathrm{~A}$ ), but increased staining in the neuropil of anesthetized mice and some somatic staining (Fig. 6B). PHF-1 staining was also observed in the neuropil of control mice, but it extended to the somatodendritic compartment after anesthesia (Fig. $6 C, D)$. These results confirm our immunoblot data which re- 

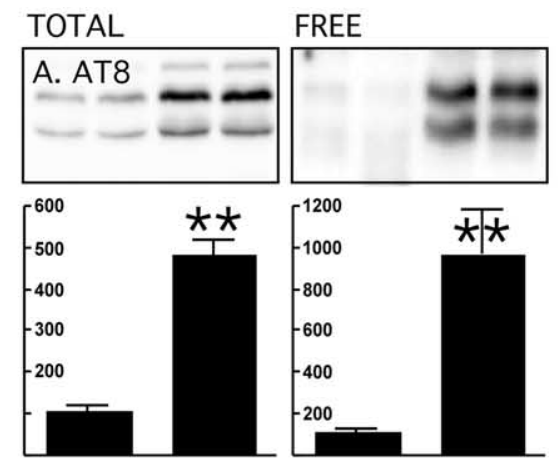

BOUND
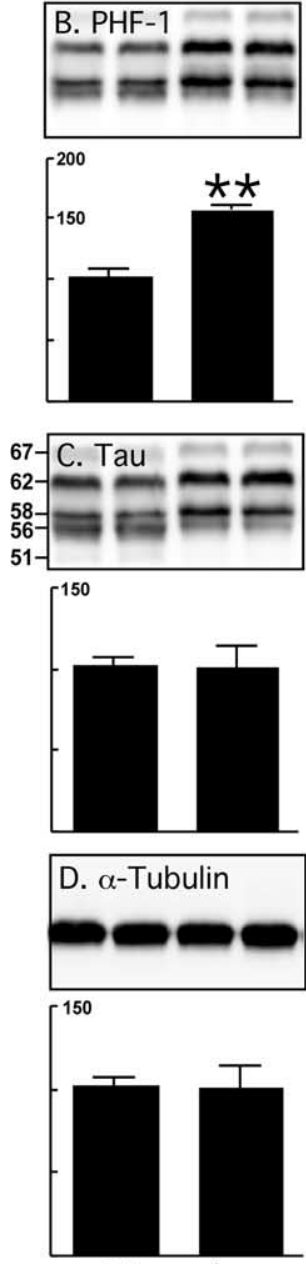

$\mathrm{Ctl}$
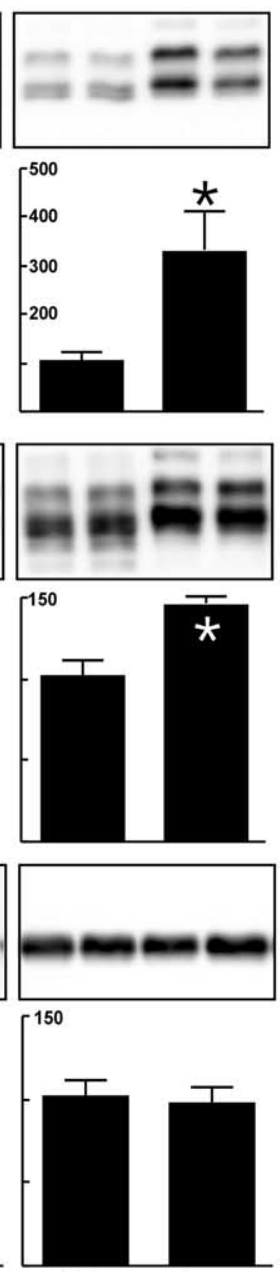

Ctl
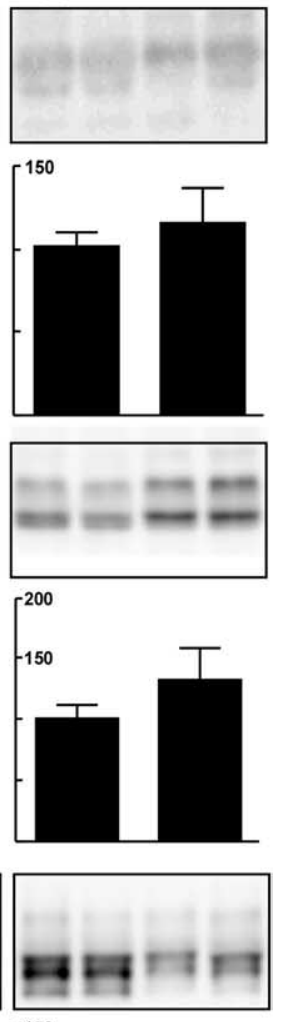

150
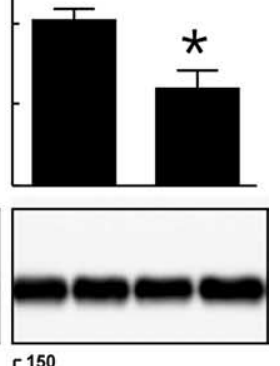

150

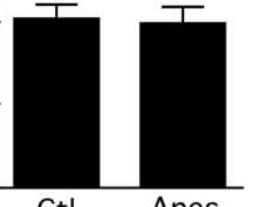

Ctl Anes

Figure 4. Endogenous microtubule binding assay of tau after anesthesia in hTau mice. Brain proteins (hippocampus and neocortex) from control mice and mice anesthetized for $4 \mathrm{~h}$ with pentobarbital were extracted. Levels of tau and tubulin from total, free and bound fractions were evaluated by immunoblot analysis with the following antibodies: $\boldsymbol{A}, \mathrm{AT} 8\left(\mathrm{pS}^{202} / \mathrm{pT}^{205}\right) ; \boldsymbol{B}$, PHF-1 ( $\mathrm{pS}^{396} / \mathrm{pS}^{404}$ ); $\boldsymbol{C}$, Tau (phospho-independent, molecular weights in kDa indicated on the left); $\boldsymbol{D}, \alpha$-tubulin. Bar graphs represent the quantification of the immunoblot bands displayed above them. Each graph displays the immunoreactivity expressed as a percentage of the control (100\%). Numbers in the graphs indicate the percentage of the tick line with which they are aligned. Data represented are means $\pm S D$ ( $n=4$ for each condition, two representative data displayed, each lane represents an individual mouse). Asterisks indicate significant differences from controls, with ${ }^{*} p<0.05$ and ${ }^{* *} p<0.01$.

vealed a robust increase in phosphorylation at $\mathrm{S}^{202} / \mathrm{T}^{205}$ (Fig. $4 \mathrm{~A}$ ) but less change in phosphorylation at the $\mathrm{S}^{396} / \mathrm{S}^{404}$ epitopes (Fig. $4 B$ ). Our data suggest that tau in cell bodies is more readily phosphorylated at the $\mathrm{S}^{396} / \mathrm{S}^{404}$ epitopes. We next examined the gross

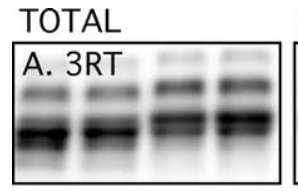

FREE
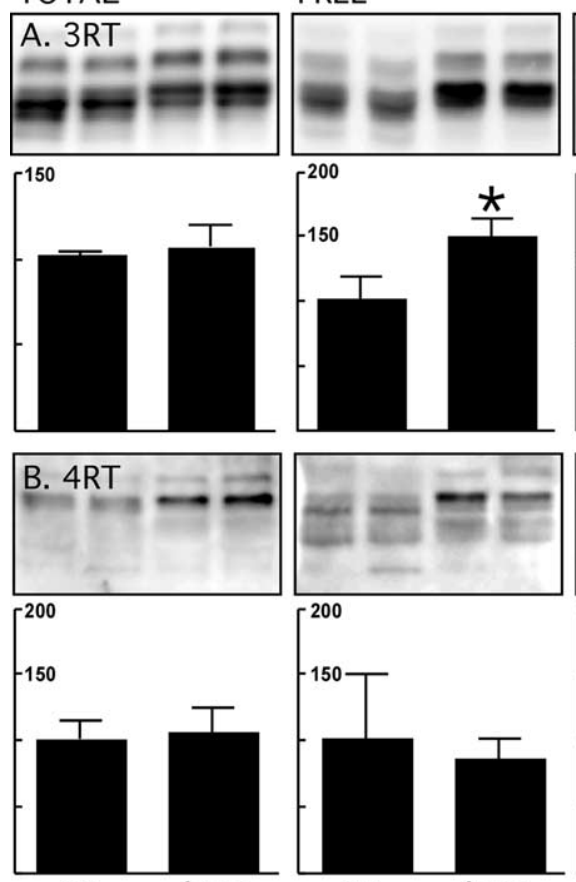

Ctl
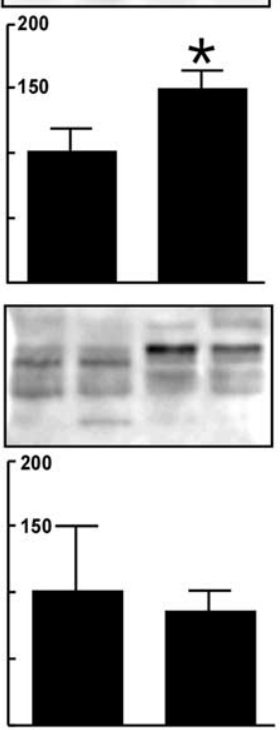

Ctl

Anes
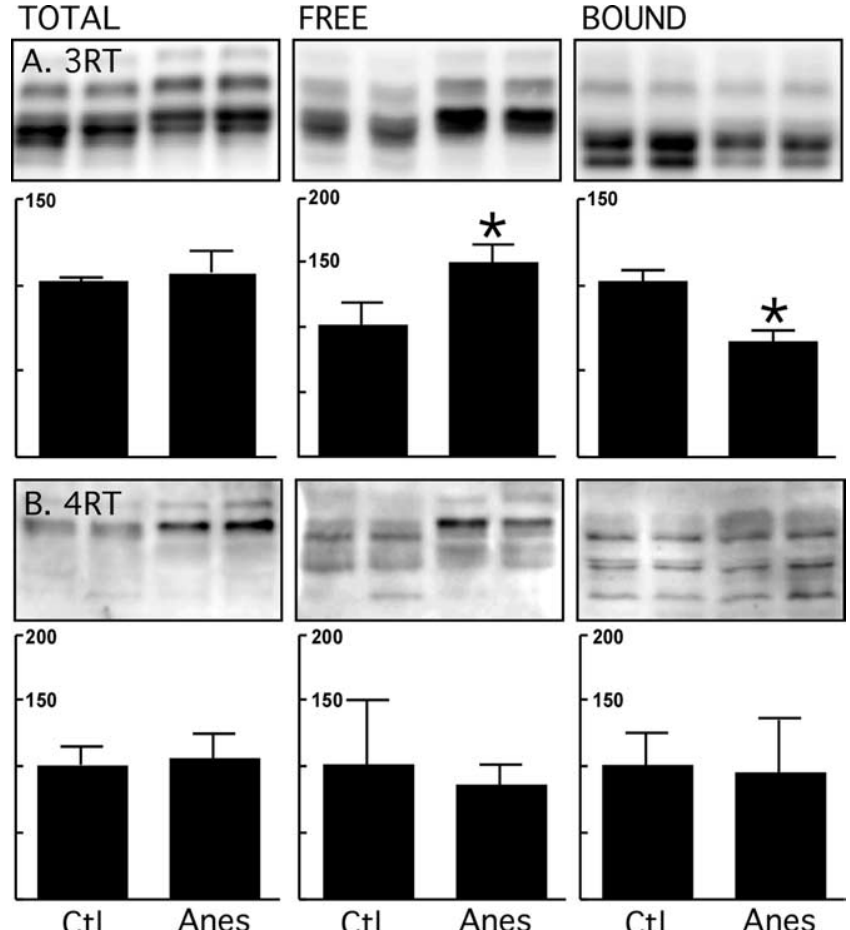

Figure 5. Endogenous microtubule binding assay of tau isoforms after anesthesia in hTau mice. Brain proteins (hippocampus and neocortex) from control mice and mice anesthetized for $4 \mathrm{~h}$ with pentobarbital were extracted. Tau Total, Free, and Bound fractions were evaluated by immunoblot analysis with the following antibodies: $\boldsymbol{A}, \mathrm{RD} 3$, 3-repeat tau; $\boldsymbol{B}, \mathrm{RD} 4$, 4-repeat tau. Bar graphs represent the quantification of the immunoblot bands displayed above them. Each graph displays the immunoreactivity expressed as a percentage of the control (100\%). Numbers in the graphs indicate the percentage of the tick line with which they are aligned. Data represented are means \pm SD $(n=4$ for each condition, two representative data displayed, each lane represents an individual mouse). Asterisks indicate significant differences from controls, with ${ }^{*} p<0.05$.

anatomical distribution of tau in hTau mice. In unanesthetized, control hTau mice, total tau (Fig. 6E, Tau, phospho-independent tau), and 3R tau (Fig. 6 H, 3RT) were present in the neuropil and in the soma of neurons. After anesthesia, there was no difference in staining with total tau (Fig. $6 F$ ), but there was a visible increase of 3RT signal in the soma relative to control animals (compare Fig. $6 H, I$ ). This could be because of an accumulation of $3 \mathrm{R}$ tau in the soma after anesthesia, or the result of conformational changes making the repeat region more accessible to the antibody. Staining with $4 \mathrm{R}$ tau specific antibody revealed the neuropil localization of $4 \mathrm{R}$ tau, but no difference in distribution was observed after anesthesia (Fig. $6 \mathrm{~K}, \mathrm{~L}$ ). None of the antibodies immunolabeled the tau knock-out mouse brain tissue, confirming their specificity for tau (Fig. $6 G, J, M$ ). Thus, anesthesia appeared to induce hyperphosphorylation of tau in the soma and the neuropil of hTau mice, that correlates with the specific detachment of $3 \mathrm{R}$ tau from MT observed previously (Fig. 5A).

Anesthesia does not induce MT reorganization in the optic nerve

To investigate the effect of hyperphosphorylation on the organization of the axonal cytoskeleton, we examined the ultrastructure of the optic nerve from control and anesthetized old hTau mice. Initial immunoblot studies confirmed that tau was hyperphosphorylated to a similar extent in this region as in the brain (data not shown). Inspection of electron micrographs from three mice in each group revealed no difference in the number of MTs or 
their spatial relationship to each other, and to neurofilaments, in axons of varying caliber (Fig. 7). These results demonstrate that detachment of $3 \mathrm{R}$ tau from the MTs did not induce MT reorganization in the axonal tracks of the optic nerve.

\section{Discussion}

The induction tau hyperphosphorylation through anesthesia-induced hypothermia allowed us to investigate the effect of hyperphosphorylation on tau's interaction with MTs in vivo. First, we have shown that under these conditions, MT-free tau was rapidly, and extensively hyperphosphorylated, impairing its capacity to bind MT and to promote MT assembly. Second, MT bound tau was more resistant to phosphorylation than free tau, and only $3 \mathrm{R}$ tau detached from MT in a transgenic line of mice expressing both $3 \mathrm{R}$ and $4 \mathrm{R}$ human tau with mild pathology. Third, even when 3R tau separated from MTs, there was no depolymerization of tubulin in the MTbound fraction, and there was no collapse or disturbance of axonal MT networks.

Hyperphosphorylation of tau induced by kinase activity in cells and in vitro has repeatedly demonstrated that hyperphosphorylation impairs tau's capacity to bind MT and to promote MT assembly. Inhibition of PP2A in cells also leads to tau hyperphosphorylation and renders it incompetent to associate with exogenous MTs (Shea and Fischer, 1996; Sontag et al., 1996). Thus, our data from wild-type mice confirm and extend these reports and represent the first demonstration that inhibition of PP2A by anesthesia-induced hypothermia in vivo (Planel et al., 2007b) results in hyperphosphorylation of MT-free tau which reduces its ability to bind and assemble MTs.

In contrast to free tau, MT-bound tau was resistant to phosphorylation at many epitopes, including $\mathrm{S}^{202} / \mathrm{T}^{205}$ (AT8), $\mathrm{T}^{231}$ (TG3), $\mathrm{S}^{235}$ (MC6), $\mathrm{S}^{262} / \mathrm{S}^{356}$ (12E8) and $\mathrm{S}^{422}$, which might be the result of poor kinase accessibility of these residues when tau is associated with MTs. $S^{262}$ in the MTbound fraction proved to be especially resistant to phosphorylation, even after $3 \mathrm{~d}$ of hyperphosphorylation conditions. However, other sites on MT-bound tau such as sites recognized by $\mathrm{S}^{199}, \mathrm{~S}^{202}$ (CP13), or $\mathrm{S}^{396} / \mathrm{S}^{404}$ (PHF-1) were hyperphosphorylated, which suggest that the conformation that tau takes on MTs leaves these epitopes accessible to phosphorylation events, and that they are less likely to regulate tau binding. Indeed, phosphorylation at sites such as $\mathrm{T}^{231}, \mathrm{~T}^{231} / \mathrm{S}^{235}, \mathrm{~S}^{262}$, or $\mathrm{S}^{262} / \mathrm{S}^{356}$ prevents tau from binding and stabilizing MTs (Biernat et al., 1993; Sengupta et al., 1998; Hamdane et al., 2003; Cho and Johnson, 2004), whereas phosphorylation at $S^{202}, S^{396}, S^{396} / S^{404}$, or $S^{404}$ seems to have less impact on MT binding (Biernat et al., 1993; Cho and Johnson, 2003). When we applied the same experimental paradigm to hTau mice, we obtained similar results to nontransgenic mice: total and free tau (but not bound tau) was significantly
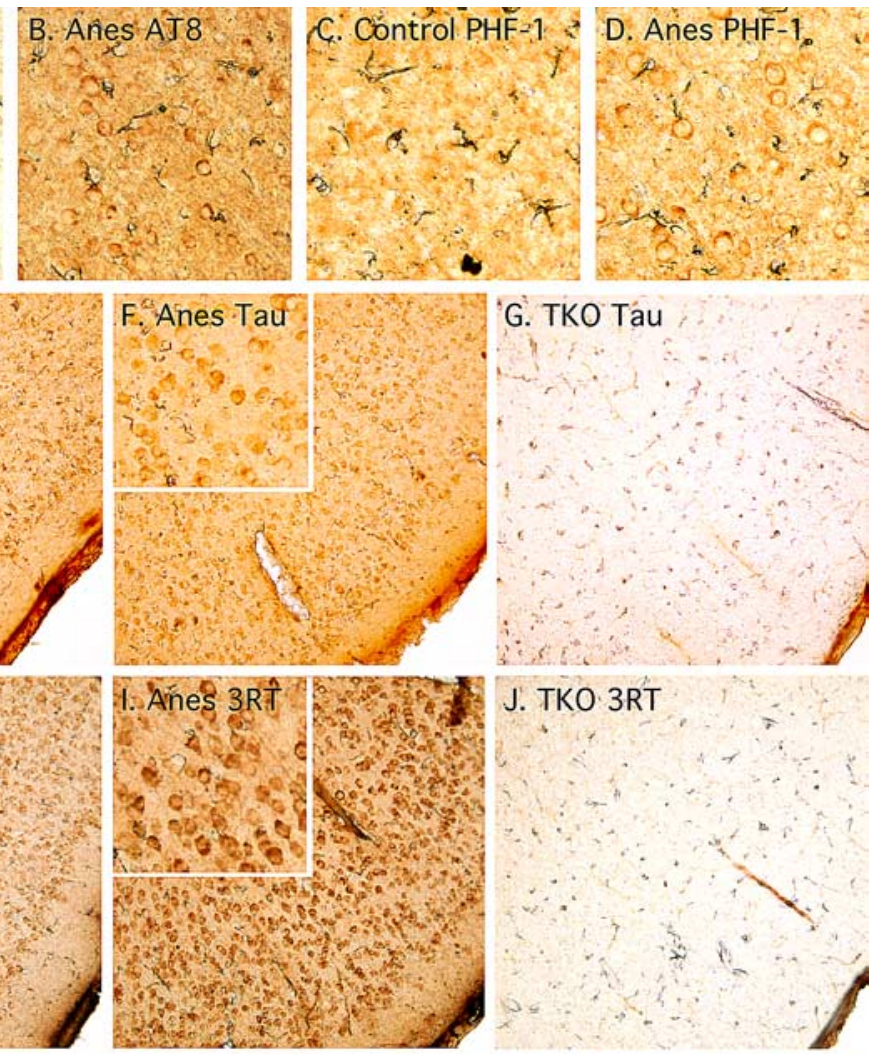

J. TKO $3 R T$
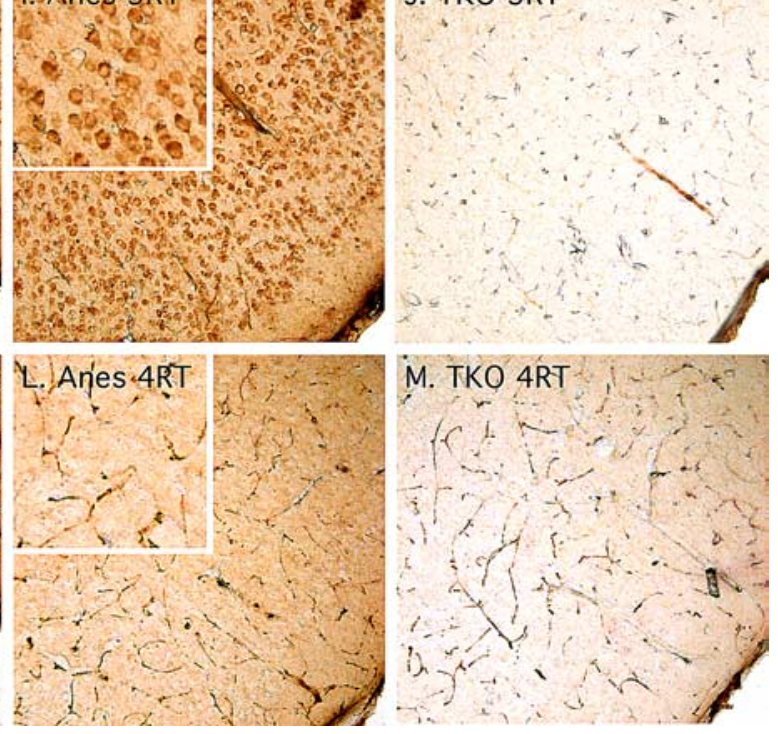

Figure 6. Tau immunostaining in the frontal cortex after anesthesia in $\mathrm{hTau}$ mice. Sagittal sections from control $(\boldsymbol{A}, \boldsymbol{C}, \boldsymbol{E}, \boldsymbol{H}, \boldsymbol{K})$, anesthetized $(\boldsymbol{B}, \boldsymbol{D}, \boldsymbol{F}, \boldsymbol{I}, \boldsymbol{L}) \mathrm{hTau}$, or TKO (tau knock-out, used as negative staining control; $\boldsymbol{G}, \boldsymbol{J}, \boldsymbol{M}$ ) mice were immunolabeled with the following antibodies: $\boldsymbol{A}, \boldsymbol{B}$, AT8 $\left(\mathrm{pS}^{202} / \mathrm{pT}^{205}\right) ; \boldsymbol{C}, \boldsymbol{D}$, PHF-1 ( $\left.\mathrm{pS}^{396} / \mathrm{pS}^{404}\right) ; \boldsymbol{E}-\boldsymbol{G}$, Tau (phospho-independent); $\boldsymbol{H}-\boldsymbol{J}, \mathrm{RD} 3$ (3-repeat tau); $\boldsymbol{K}-\boldsymbol{M}, \mathrm{RD} 4$ (4-repeat tau). Magnification is $200 \times$ for all of the micrographs.

phosphorylated at $S^{202} / \mathrm{T}^{205}$, whereas total, free and bound tau were hyperphosphorylated at $\mathrm{S}^{396} / \mathrm{S}^{404}$. These results demonstrate that pools of MT-free and bound tau have a different sensitivity to hyperphosphorylating conditions.

When we examined the association of tau bound with endogenous MTs in response to hyperphosphorylating conditions during anesthesia, we found in wild-type mice that $4 \mathrm{R}$ tau did not separate from MTs independently of age. This is unlikely to be the result of a protective effect of hypothermia, as we showed previously that a low but sustained level of tau hyperphosphorylation in normothermic mice does not impair tau binding to MTs (Planel et al., 2007a). Also, the resistance to dissociation is probably a true failure to dissociate rather than a mere kinetic delay of dissociation, because we examined the mice $1 \mathrm{~d}$ and 1 week after anesthesia and did not see any significant change in total tau or tubulin in the different fractions (data not shown). In old hTau mice with mild pathology, there was an isoform specific dissociation of tau from MTs, as 3R, but not $4 \mathrm{R}$ tau, was detached. These results suggest that, in a pathological context, bound $3 \mathrm{R}$ tau is 

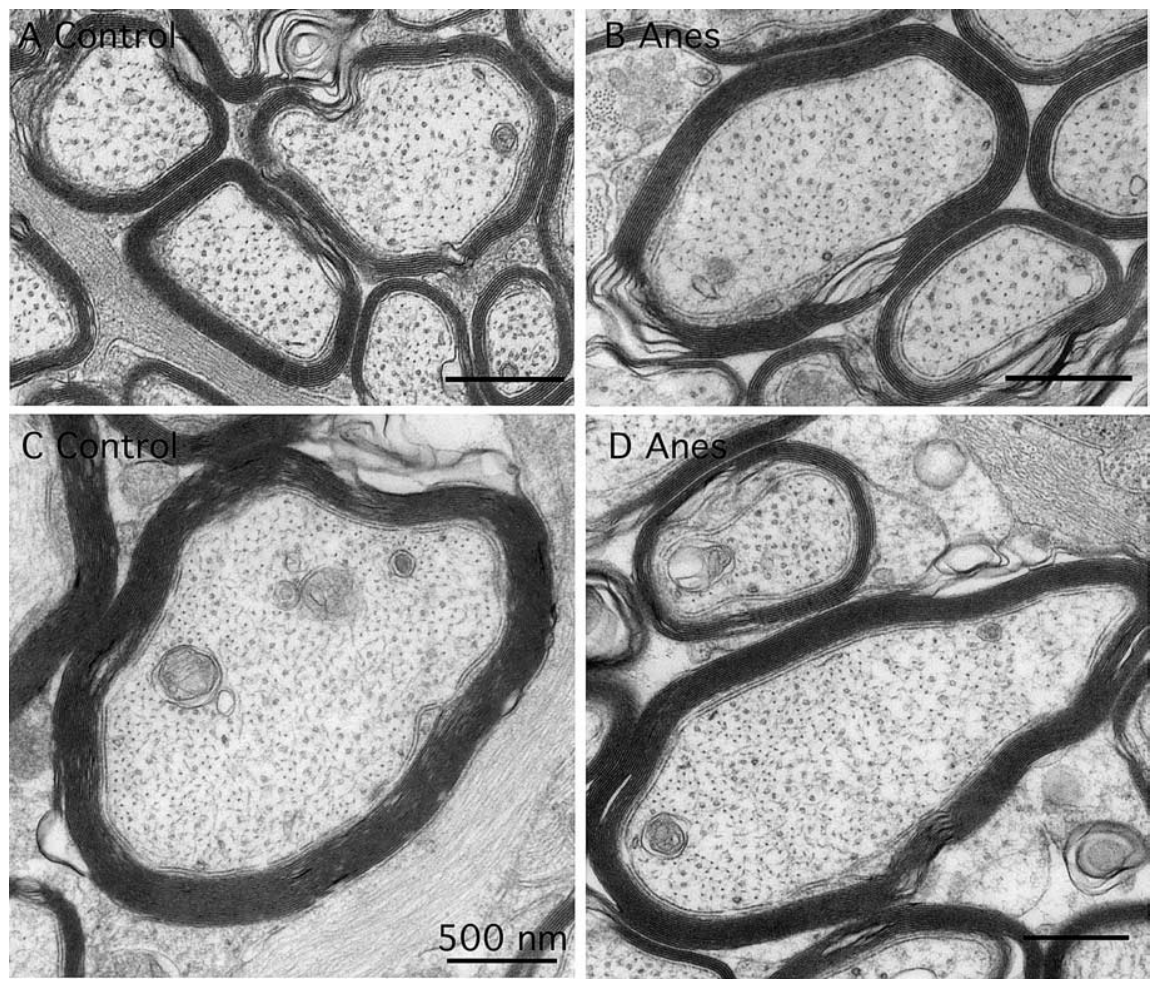

Figure 7. Ultrastructure of the cytoskeleton in axons of varying caliber from the optic nerve of control $(\boldsymbol{A}, \boldsymbol{C})$ and anesthetized $(\boldsymbol{B}, \boldsymbol{D})$ mice. There was no difference in numbers and the spatial relationships among microtubules, neurofilaments, and vesicular organelles.

more sensitive than $4 \mathrm{R}$ to the effects of phosphorylation resulting in dissociation. 3R tau has been demonstrated to bind to MTs more weakly than $4 \mathrm{R}$ tau (Butner and Kirschner, 1991), and to be less efficient at promoting microtubule assembly (Goedert and Jakes, 1990; Gustke et al., 1994; Panda et al., 2003). In addition, published results suggest that $3 \mathrm{R}$ and $4 \mathrm{R}$ tau assume complex and distinct MT binding structures (Goode et al., 2000). Thus, the specific dissociation of 3R tau in old hTau mice might be caused by a combination of a higher baseline of phosphorylation resulting from pathology, weaker interactions with MTs, and greater accessibility to phosphorylation agents because of a different structural conformation on the surface of MTs.

Even when $3 \mathrm{R}$ tau dissociated from the MTs, depolymerization and collapse of the MT networks did not occur. One explanation might be that the remaining tau bound to MTs was sufficient enough to stabilize the cytoskeletal structure. Indeed, tau has been found to fulfill its stabilizing function in very minute amounts (Levy et al., 2005). Another possibility comes from the suggestion that $3 \mathrm{R}$ and $4 \mathrm{R}$ tau might have distinct functions on MTs that are regulated differentially (Goode et al., 2000); thus, if $4 \mathrm{R}$ tau were the primary stabilizer of MTs in vivo, detachment of 3R only would have no impact on MT networks. These results are in marked contrast with others reported in the literature: all of the data from cell culture studies demonstrate that tau hyperphosphorylation mediated by kinase overactivation or phosphatase inhibition results in tau dissociation from MTs and destruction of MT networks (Gurland and Gundersen, 1993; Sontag et al., 1996; Merrick et al., 1997; Kim et al., 1999). This discrepancy might be attributable to the difference in the speed of the assembly process between cellular models and living animals. MT function requires dynamic equilibrium between the formation of polymerized and depolymerized MTs (Desai and Mitchison, 1997).
For example, in fibroblasts, turnover can be very fast: tubulin protomers have a halflife of $1 \mathrm{~d}$, but the MTs formed from them are very dynamic $\left(t_{1 / 2} \sim 5-10 \mathrm{~min}\right.$; Schulze and Kirschner, 1987). In vitro studies on cultured neurons show that growing axons contain a high percentage of stable MT polymers with a half-life of $>2 \mathrm{~h}$ ( $\mathrm{Li}$ and Black, 1996). In vivo, MTs in mature axons are likely to be even more stable, and studies suggest that some MTs can last for months (Garner, 1988; Tanner et al., 1995). Thus, longer exposure to hyperphosphorylating conditions in vivo (months or years instead of hours or days) might result in less $4 \mathrm{R}$ tau bound to MTs and might lead to partial MT collapse. However, this would be more likely the result of MT turnover and the failure of MTs to recruit hyperphosphorylated free tau rather than dissociation of $4 \mathrm{R}$ tau already bound to MTs.

Our results might have clinical relevance, as anesthesia appears to be associated with long-term cognitive dysfunction and the acceleration of senile dementia (Ritchie et al., 1997; Xie and Tanzi, 2006). Several reports have suggested that anesthesia could increase the risk of $\mathrm{AD}$ (Bohnen et al., 1994; Johansson and Skoog, 1996; Bone and Rosen, 2000), and hypothermia has also been proposed as a risk factor (Holtzman and Simon, 2000; Avila and Díaz-Nido, 2004). The combination of regional or general anesthetic exposure and cool operating room environment make most surgical patients hypothermic (Sessler, 2000). Although hypothermia may be beneficial for specific, critically ill patients, perioperative hypothermia after anesthesia is clearly harmful for most patients (Sessler, 1997, 2001). It is therefore encouraging for surgery patients that tau hyperphosphorylation after $4 \mathrm{~h}$ of anesthesia did not lead to a collapse of MTs. However, the fact that this detachment occurs only when the mice are older and have mild pathology underscores the vulnerability of the elderly, particularly if they have incipient AD. Interestingly, studies on tau splicing in embryos suggest that $3 \mathrm{R}$ tau could permit a higher degree of neuronal plasticity, as it is the main isoform expressed during early development (Kosik et al., 1989; Avila et al., 1994; Janke et al., 1999; Takuma et al., 2003). In addition, tau isoforms seem to have opposite effects on MT, with $4 \mathrm{R}$ tau promoting and $3 \mathrm{R}$ tau reducing MT growth rate, which may be used by the cells to finely regulate MT dynamics (Levy et al., 2005). Thus, specific detachment of 3R tau after anesthesia might have the counter-intuitive effect of decreasing MT dynamics and neuronal plasticity. Whether 3R tau detachment could have any role in the postoperative cognitive dysfunction that is common after general anesthesia remains an open question (Ancelin et al., 2001). Last, it should be noted that our study was done with pentobarbital, an intravenous anesthetics not known to interact with MTs. In contrast, volatile anesthetics have been shown to interact directly with tubulin, alter MTs quaternary structure, affect tubulin expression, and reduce MT density in neurons (for review, see Eckenhoff and Eckenhoff, 2007). Future studies should therefore examine the effect of volatile anesthetics on tau 
phosphorylation and MT stability, with and without hypothermia.

Overall, our data imply that MTs do not easily disassemble in mammals, and provide limiting parameters to any putative disassembly of MTs resulting from tau hyperphosphorylation rather than disprove that it would occur. In vivo hyperphosphorylation of tau seems more likely to affect MT networks in the long term, by preventing free tau from binding and stabilizing MTs, rather than by overtly dissociating tau already bound to them.

\section{References}

Alonso A, Zaidi T, Novak M, Grundke-Iqbal I, Iqbal K (2001) Hyperphosphorylation induces self-assembly of tau into tangles of paired helical filaments / straight filaments. Proc Natl Acad Sci U S A 98:6923-6928.

Alonso Adel C, Li B, Grundke-Iqbal I, Iqbal K (2006) Polymerization of hyperphosphorylated tau into filaments eliminates its inhibitory activity. Proc Natl Acad Sci U S A 103:8864-8869.

Ancelin ML, de Roquefeuil G, Ledésert B, Bonnel F, Cheminal JC, Ritchie K (2001) Exposure to anaesthetic agents, cognitive functioning and depressive symptomatology in the elderly. Br J Psychiatry 178:360-366.

Andorfer C, Kress Y, Espinoza M, de Silva R, Tucker KL, Barde YA, Duff K, Davies P (2003) Hyperphosphorylation and aggregation of tau in mice expressing normal human tau isoforms. J Neurochem 86:582-590.

Avila J, Díaz-Nido J (2004) Tangling with hypothermia. Nat Med 10:460-461.

Avila J, Dominguez J, Díaz-Nido J (1994) Regulation of microtubule dynamics by microtubule-associated protein expression and phosphorylation during neuronal development. Int J Dev Biol 38:13-25.

Avila J, Lucas JJ, Perez M, Hernandez F (2004) Role of tau protein in both physiological and pathological conditions. Physiol Rev 84:361-384.

Biernat J, Gustke N, Drewes G, Mandelkow EM, Mandelkow E (1993) Phosphorylation of Ser262 strongly reduces binding of tau to microtubules: distinction between PHF-like immunoreactivity and microtubule binding. Neuron 11:153-163.

Bohnen N, Warner MA, Kokmen E, Kurland LT (1994) Early and midlife exposure to anesthesia and age of onset of Alzheimer's disease. Int J Neurosci 77:181-185.

Bone I, Rosen M (2000) Alzheimer's disease and anaesthesia. Anaesthesia 55:592-593.

Bramblett GT, Goedert M, Jakes R, Merrick SE, Trojanowski JQ, Lee VM (1993) Abnormal tau phosphorylation at Ser396 in Alzheimer's disease recapitulates development and contributes to reduced microtubule binding. Neuron 10:1089-1099.

Buée L, Bussière T, Buée-Scherrer V, Delacourte A, Hof PR (2000) Tau protein isoforms, phosphorylation and role in neurodegenerative disorders. Brain Res Brain Res Rev 33:95-130.

Butner KA, Kirschner MW (1991) Tau protein binds to microtubules through a flexible array of distributed weak sites. J Cell Biol 115:717-730.

Cho JH, Johnson GV (2003) Glycogen synthase kinase 3beta phosphorylates tau at both primed and unprimed sites. Differential impact on microtubule binding. J Biol Chem 278:187-193.

Cho JH, Johnson GV (2004) Primed phosphorylation of tau at Thr231 by glycogen synthase kinase 3beta (GSK3beta) plays a critical role in regulating tau's ability to bind and stabilize microtubules. J Neurochem 88:349-358.

Desai A, Mitchison TJ (1997) Microtubule polymerization dynamics. Annu Rev Cell Dev Biol 13:83-117.

de Silva R, Lashley T, Gibb G, Hanger D, Hope A, Reid A, Bandopadhyay R, Utton M, Strand C, Jowett T, Khan N, Anderton B, Wood N, Holton J, Revesz T, Lees A (2003) Pathological inclusion bodies in tauopathies contain distinct complements of tau with three or four microtubulebinding repeat domains as demonstrated by new specific monoclonal antibodies. Neuropathol Appl Neurobiol 29:288-302.

Duff K, Knight H, Refolo LM, Sanders S, Yu X, Picciano M, Malester B, Hutton M, Adamson J, Goedert M, Burki K, Davies P (2000) Characterization of pathology in transgenic mice over-expressing human genomic and cDNA tau transgenes. Neurobiol Dis 7:87-98.

Ebneth A, Drewes G, Mandelkow EM, Mandelkow E (1999) Phosphorylation of MAP2c and MAP4 by MARK kinases leads to the destabilization of microtubules in cells. Cell Motil Cytoskeleton 44:209-224.
Eckenhoff RG, Eckenhoff MF (2007) Anesthesia, amyloid and Alzheimer's. Cell Sci Rev 4:78-96.

Esmaeli-Azad B, McCarty JH, Feinstein SC (1994) Sense and antisense transfection analysis of tau function: tau influences net microtubule assembly, neurite outgrowth and neuritic stability. J Cell Sci 107 (Pt 4):869-879.

Feinstein SC, Wilson L (2005) Inability of tau to properly regulate neuronal microtubule dynamics: a loss-of-function mechanism by which tau might mediate neuronal cell death. Biochim Biophys Acta 1739:268-279.

Garner JA (1988) Differential turnover of tubulin and neurofilament proteins in central nervous system neuron terminals. Brain Res 458:309-318.

Goedert M, Jakes R (1990) Expression of separate isoforms of human tau protein: correlation with the tau pattern in brain and effects on tubulin polymerization. EMBO J 9:4225-4230.

Goedert M, Jakes R, Vanmechelen E (1995) Monoclonal antibody AT8 recognises tau protein phosphorylated at both serine 202 and threonine 205. Neurosci Lett 189:167-169.

Gong CX, Singh TJ, Grundke-Iqbal I, Iqbal K (1993) Phosphoprotein phosphatase activities in Alzheimer disease brain. J Neurochem 61:921-927.

Gong CX, Shaikh S, Wang JZ, Zaidi T, Grundke-Iqbal I, Iqbal K (1995) Phosphatase activity toward abnormally phosphorylated tau: decrease in Alzheimer disease brain. J Neurochem 65:732-738.

Goode BL, Chau M, Denis PE, Feinstein SC (2000) Structural and functional differences between 3-repeat and 4-repeat Tau isoforms. Implications for normal tau function and the onset of neurodegenerative disease. J Biol Chem 275:38182-38189.

Gurland G, Gundersen GG (1993) Protein phosphatase inhibitors induce the selective breakdown of stable microtubules in fibroblasts and epithelial cells. Proc Natl Acad Sci U S A 90:8827-8831.

Gustke N, Trinczek B, Biernat J, Mandelkow EM, Mandelkow E (1994) Domains of tau protein and interactions with microtubules. Biochemistry 33:9511-9522.

Hamdane M, Sambo AV, Delobel P, Bégard S, Violleau A, Delacourte A, Bertrand P, Benavides J, Buée L (2003) Mitotic-like tau phosphorylation by p25-Cdk5 kinase complex. J Biol Chem 278:34026-34034.

Holtzman A, Simon EW (2000) Body temperature as a risk factor for Alzheimer's disease. Med Hypotheses 55:440-444.

Janke C, Beck M, Stahl T, Holzer M, Brauer K, Bigl V, Arendt T (1999) Phylogenetic diversity of the expression of the microtubule-associated protein tau: implications for neurodegenerative disorders. Brain Res Mol Brain Res 68:119-128.

Jicha GA, Lane E, Vincent I, Otvos L Jr, Hoffmann R, Davies P (1997) A conformation- and phosphorylation-dependent antibody recognizing the paired helical filaments of Alzheimer's disease. J Neurochem 69:2087-2095.

Johansson C, Skoog I (1996) A population-based study on the association between dementia and hip fractures in 85-year olds. Aging (Milano) 8:189-196.

Kim D, Su J, Cotman CW (1999) Sequence of neurodegeneration and accumulation of phosphorylated tau in cultured neurons after okadaic acid treatment. Brain Res 839:253-262.

Kosik KS, Orecchio LD, Bakalis S, Neve RL (1989) Developmentally regulated expression of specific tau sequences. Neuron 2:1389-1397.

Levy SF, Leboeuf AC, Massie MR, Jordan MA, Wilson L, Feinstein SC (2005) Three- and four-repeat tau regulate the dynamic instability of two distinct microtubule subpopulations in qualitatively different manners. Implications for neurodegeneration. J Biol Chem 280:13520-13528.

Li Y, Black MM (1996) Microtubule assembly and turnover in growing axons. J Neurosci 16:531-544.

Maas T, Eidenmüller J, Brandt R (2000) Interaction of tau with the neural membrane cortex is regulated by phosphorylation at sites that are modified in paired helical filaments. J Biol Chem 275:15733-15740.

Mandelkow EM, Stamer K, Vogel R, Thies E, Mandelkow E (2003) Clogging of axons by tau, inhibition of axonal traffic and starvation of synapses. Neurobiol Aging 24:1079-1085.

Merrick SE, Demoise DC, Lee VM (1996) Site-specific dephosphorylation of tau protein at Ser202/Thr205 in response to microtubule depolymerization in cultured human neurons involves protein phosphatase 2A. J Biol Chem 271:5589-5594.

Merrick SE, Trojanowski JQ, Lee VM (1997) Selective destruction of stable microtubules and axons by inhibitors of protein serine/threonine phosphatases in cultured human neurons. J Neurosci 17:5726-5737.

Mi K, Johnson GV (2006) The role of tau phosphorylation in the pathogenesis of Alzheimer's disease. Curr Alzheimer Res 3:449-463. 
Nixon RA, Paskevich PA, Sihag RK, Thayer CY (1994) Phosphorylation on carboxyl terminus domains of neurofilament proteins in retinal ganglion cell neurons in vivo: influences on regional neurofilament accumulation, interneurofilament spacing, and axon caliber. J Cell Biol 126:1031-1046.

O'Farrell PH (1975) High resolution two-dimensional electrophoresis of proteins. J Biol Chem 250:4007-4021.

Otvos L Jr, Feiner L, Lang E, Szendrei GI, Goedert M, Lee VM (1994) Monoclonal antibody PHF-1 recognizes tau protein phosphorylated at serine residues 396 and 404. J Neurosci Res 39:669-673.

Panda D, Samuel JC, Massie M, Feinstein SC, Wilson L (2003) Differential regulation of microtubule dynamics by three- and four-repeat tau: implications for the onset of neurodegenerative disease. Proc Natl Acad Sci U S A 100:9548-9553.

Planel E, Yasutake K, Fujita SC, Ishiguro K (2001) Inhibition of protein phosphatase $2 \mathrm{~A}$ overrides Tau protein kinase I / glycogen synthase kinase 3beta and Cyclin-dependant kinase 5 inhibition and results in tau hyperphosphorylation in the hippocampus of starved mouse. J Biol Chem 276:34298-34306.

Planel E, Miyasaka T, Launey T, Chui DH, Tanemura K, Sato S, Murayama O, Ishiguro K, Tatebayashi Y, Takashima A (2004) Alterations in glucose metabolism induce hypothermia leading to tau hyperphosphorylation through differential inhibition of kinase and phosphatase activities: implications for Alzheimer's disease. J Neurosci 24:2401-2411.

Planel E, Tatebayashi Y, Miyasaka T, Liu L, Wang L, Herman M, Yu WH, Luchsinger JA, Wadzinski B, Duff KE, Takashima A (2007a) Insulin dysfunction induces in vivo tau hyperphosphorylation through distinct mechanisms. J Neurosci 27:13635-13648.

Planel E, Richter KE, Nolan CE, Finley JE, Liu L, Wen Y, Krishnamurthy P, Herman M, Wang L, Schachter JB, Nelson RB, Lau LF, Duff KE (2007b) Anesthesia leads to tau hyperphosphorylation through inhibition of phosphatase activity by hypothermia. J Neurosci 27:3090-3097.

Pollak D, Cairns N, Lubec G (2003) Cytoskeleton derangement in brain of patients with Down syndrome, Alzheimer's disease and Pick's disease. J Neural Transm Suppl 67:149-158.

Ritchie K, Polge C, de Roquefeuil G, Djakovic M, Ledesert B (1997) Impact of anesthesia on the cognitive functioning of the elderly. Int Psychogeriatr 9:309-326.

Sato S, Tatebayashi Y, Akagi T, Chui DH, Murayama M, Miyasaka T, Planel E, Tanemura K, Sun X, Hashikawa T, Yoshioka K, Ishiguro K, Takashima A (2002) Aberrant tau phosphorylation by glycogen synthase kinase-3beta and JNK3 induces oligomeric tau fibrils in COS-7 cells. J Biol Chem 277:42060-42065.

Schulze E, Kirschner M (1987) Dynamic and stable populations of microtubules in cells. J Cell Biol 104:277-288.

Sengupta A, Kabat J, Novak M, Wu Q, Grundke-Iqbal I, Iqbal K (1998) Phosphorylation of tau at both Thr 231 and Ser 262 is required for maximal inhibition of its binding to microtubules. Arch Biochem Biophys 357:299-309.

Sessler DI (1997) Mild perioperative hypothermia. N Engl J Med 336:1730-1737.

Sessler DI (2000) Perioperative heat balance. Anesthesiology 92:578-596.

Sessler DI (2001) Complications and treatment of mild hypothermia. Anesthesiology 95:531-543.
Seubert P, Mawal-Dewan M, Barbour R, Jakes R, Goedert M, Johnson GV, Litersky JM, Schenk D, Lieberburg I, Trojanowski JQ, Lee VMY (1995) Detection of phosphorylated Ser262 in fetal tau, adult tau, and paired helical filament tau. J Biol Chem 270:18917-18922.

Shea TB, Fischer I (1996) Phosphatase inhibition in human neuroblastoma cells alters tau antigenicity and renders it incompetent to associate with exogenous microtubules. FEBS Lett 380:63-67.

Shelanski ML, Gaskin F, Cantor CR (1973) Microtubule assembly in the absence of added nucleotides. Proc Natl Acad Sci U S A 70:765-768.

Shi SR, Chaiwun B, Young L, Cote RJ, Taylor CR (1993) Antigen retrieval technique utilizing citrate buffer or urea solution for immunohistochemical demonstration of androgen receptor in formalin-fixed paraffin sections. J Histochem Cytochem 41:1599-1604.

Sontag E, Nunbhakdi-Craig V, Lee G, Bloom GS, Mumby MC (1996) Regulation of the phosphorylation state and microtubule-binding activity of Tau by protein phosphatase 2A. Neuron 17:1201-1207.

Sontag E, Luangpirom A, Hladik C, Mudrak I, Ogris E, Speciale S, White CL 3rd (2004) Altered expression levels of the protein phosphatase 2A ABalphaC enzyme are associated with Alzheimer disease pathology. J Neuropathol Exp Neurol 63:287-301.

Szendrei GI, Lee VM, Otvos L Jr (1993) Recognition of the minimal epitope of monoclonal antibody Tau- 1 depends upon the presence of a phosphate group but not its location. J Neurosci Res 34:243-249.

Takuma H, Arawaka S, Mori H (2003) Isoforms changes of tau protein during development in various species. Brain Res Dev Brain Res 142:121-127.

Tanimukai H, Grundke-Iqbal I, Iqbal K (2005) Up-regulation of inhibitors of protein phosphatase-2A in Alzheimer's disease. Am J Pathol 166:1761-1771.

Tanner SL, Storm EE, Bittner GD (1995) Maintenance and degradation of proteins in intact and severed axons: implications for the mechanisms of long-term survival of anucleate crayfish axons. J Neurosci 15:540-548.

Terry RD (1996) The pathogenesis of Alzheimer disease: an alternative to the amyloid hypothesis. J Neuropathol Exp Neurol 55:1023-1025.

Tian Q, Wang J (2002) Role of serine/threonine protein phosphatase in Alzheimer's disease. Neurosignals 11:262-269.

Trojanowski JQ, Lee VM (1994) Paired helical filament tau in Alzheimer's disease. The kinase connection. Am J Pathol 144:449-453.

Vogelsberg-Ragaglia V, Bruce J, Richter-Landsberg C, Zhang B, Hong M, Trojanowski JQ, Lee VM (2000) Distinct FTDP-17 missense mutations in tau produce tau aggregates and other pathological phenotypes in transfected CHO cells. Mol Biol Cell 11:4093-4104.

Vogelsberg-Ragaglia V, Schuck T, Trojanowski JQ, Lee VM (2001) PP2A mRNA expression is quantitatively decreased in Alzheimer's disease hippocampus. Exp Neurol 168:402-412.

Weaver CL, Espinoza M, Kress Y, Davies P (2000) Conformational change as one of the earliest alterations of tau in Alzheimer's disease. Neurobiol Aging 21:719-727.

Weisenberg RC (1972) Microtubule formation in vitro in solutions containing low calcium concentrations. Science 177:1104-1105.

Xie H, Litersky JM, Hartigan JA, Jope RS, Johnson GV (1998) The interrelationship between selective tau phosphorylation and microtubule association. Brain Res 798:173-183.

Xie Z, Tanzi RE (2006) Alzheimer's disease and post-operative cognitive dysfunction. Exp Gerontol 41:346-359. 